\title{
Development of NiAl-Based Intermetallic Alloys: Effect of Chromium Addition
}

\author{
R. Tiwari \\ Cleveland State University \\ Surendra N. Tewari \\ Cleveland State University
}

Rol/postthaipaand additional works at: https://engagedscholarship.csuohio.edu/encbe_facpub

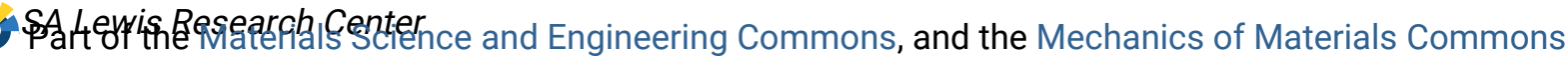
A.owarges access to this work benefit you? Let us know!

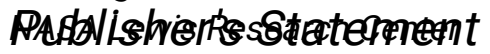

NOTICE: this is the author's version of a work that was accepted for publication in Materials Science and Engineering A. Changes resulting from the publishing process, such as peer review, editing, corrections, structural formatting, and other quality control mechanisms may not be reflected in this document. Changes may have been made to this work since it was submitted for publication. A definitive version was subsequently published in Materials Science and Engineering A, 192 -193, Part 1, (February 15, 1995) DOI 10.1016/0921-5093(94)03218-1

\section{Original Citation}

Tiwari, R., Tewari, S., Asthana, R., , \& Garg, A. (1995). Development of NiAl-based intermetallic alloys: Effect of chromium addition. Materials Science and Engineering: A, 192-193, 356-363.

\section{Repository Citation}

Tiwari, R.; Tewari, Surendra N.; Asthana, R.; and Garg, A., "Development of NiAl-Based Intermetallic Alloys: Effect of Chromium Addition" (1995). Chemical \& Biomedical Engineering Faculty Publications. 56.

https://engagedscholarship.csuohio.edu/encbe_facpub/56

This Article is brought to you for free and open access by the Chemical \& Biomedical Engineering Department at EngagedScholarship@CSU. It has been accepted for inclusion in Chemical \& Biomedical Engineering Faculty Publications by an authorized administrator of EngagedScholarship@CSU. For more information, please contact library.es@csuohio.edu. 


\title{
Development of NiAl-based intermetallic alloys: effect of chromium addition
}

\author{
R. Tiwari ${ }^{\mathrm{a}}$, S.N. Tewari ${ }^{\mathrm{a}}$, R. Asthana ${ }^{\mathrm{b}}$, A. Garg ${ }^{\mathrm{b}}$ \\ ${ }^{a}$ Chemical Engineering Department, Cleveland State University, Cleveland, OH 44115, USA \\ ${ }^{b}$ Materials Division, NASA Lewis Research Center, Cleveland, OH 44135, USA
}

\begin{abstract}
The mechanical behavior of dual-phase $\mathrm{NiAl}(\mathrm{Cr})$ microstructures, consisting of elongated primary $\mathrm{NiAl}$ grains aligned with an intergranular $\mathrm{NiAl}-\mathrm{Cr}$ eutectic phase, produced by extrusion of a cast $\mathrm{NiAl}(\mathrm{Cr})$ alloy, has been examined. Chromium addition to create a dual phase NiAl-based aligned microstructure leads to large increases in the yield strength but no significant toughness improvement. This is achieved primarily by solid solution hardening and precipitation hardening. The constitutional hardening rate resulting from deviations from stoichiometry in the nickel-rich NiAl was estimated to be about $66 \mathrm{MPa}$ per atomic per cent of nickel.
\end{abstract}

Keywords: Nickel; Aluminium; Chromium; Intermetallics; Alloys

\section{Introduction}

It is now widely recognized that large-scale use of the intermetallic $\beta$-NiAl for high temperature applications is limited, owing to its lack of room temperature ductility and toughness $[1,2]$. Of the various attempts to enhance the ductility of $\mathrm{NiAl}[3-5]$, ductile phase toughening [6] appears to be particularly promising. The first evidence of ductile phase toughening of $\mathrm{NiAl}$, with a room temperature tensile ductility of $17 \%$, was provided in an in situ composite of directionally solidified (DS) $\mathrm{Ni}-34 \mathrm{Fe}-9.9 \mathrm{Cr}-18.2 \mathrm{Al}$ alloy whose microstructure consisted of alternating lamellae of a nickel-rich f.c.c. solid solution $(\gamma)$ phase and $\beta$, phase [7]. Similarly, a room temperature ductility of about $10 \%$ was obtained in a DS Ni-30Al alloy which had aligned rod-like $\gamma^{\prime}$ in a $\beta$-NiAl matrix. A DS $\mathrm{Ni}-30 \mathrm{Fe}-20 \mathrm{Al}$ alloy containing aligned $\beta-\mathrm{NiAl}$ and $\gamma+\gamma^{\prime}$ phases showed $10 \%$ ductility [6].

Heat treatment of extruded $\mathrm{Ni}-30 \mathrm{Al}-20 \mathrm{Co}$ and $\mathrm{Ni}-36 \mathrm{Al}$ alloys to obtain equiaxed $\beta-\mathrm{NiAl}$ grains containing a necklace of continuous $\gamma^{\prime}$ at the grain boundary [8] yielded $0.5 \%$ ductility compared with almost zero ductility for alloys without $\gamma^{\prime}$. Room temperature tensile ductilities of $2 \%-6 \%$ were obtained [9] in forged and rolled $\mathrm{Ni}-20 \mathrm{Cr}-20 \mathrm{Al}$, $\mathrm{Ni}-25 \mathrm{Al}-18 \mathrm{Fe}, \mathrm{Ni}-15 \mathrm{Al}-65 \mathrm{Fe}$ and $\mathrm{Ni}-26 \mathrm{Al}-50 \mathrm{Co}$ alloys, with microstructures containing uniform distributions of equiaxed $\beta$ and $\gamma$ grains. Extruded $\mathrm{Ni}-20 \mathrm{Al}-30 \mathrm{Fe}$ cast alloy with fine equiaxed $\beta$ strains distributed in $\beta+\gamma^{\prime}$ eutectic [10] showed a room temperature ductility of $8 \%-22 \%$, depending upon the fineness of the $\gamma^{\prime}$ grains.

The ductility enhancement in these alloys is attributed to $[6,11]$ inhibition of crack nucleation in the $\beta$ phase, resulting from the increased mobile dislocation density, and inhibition of crack propagation by plastic stretching of the ductile phase in the crack (crack bridging). However, the large quantities of alloying elements used in the above alloys would adversely affect the high melting point, low density and outstanding oxidation resistance of $\mathrm{NiAl}$.

In this exploratory research, a dual-phase microstructure was produced in $\mathrm{NiAl}$ with small chromium additions, and its room temperature and elevated temperature mechanical properties were characterized. The extrusion of cast $\mathrm{NiAl}-\mathrm{Cr}$ alloy consisting of proeutectic $\beta$ grains surrounded by a small amount of intergranular eutectic may result in $\beta$ grains aligned with the extrusion direction, and the intergranular regions occupied by a chromium phase. The small solid solubility of chromium in $\beta-\mathrm{NiAl}$ in the temperature regime of $\mathrm{NiAl}$ extrusion, i.e. $1300-1450 \mathrm{~K}$, indicates that relatively small chromium additions may 
be sufficient to yield the stable two-phase microstructure at the extrusion temperatures.

\section{Experimental procedure}

The $\mathrm{NiAl}$ and $\mathrm{NiAl}(\mathrm{Cr})$ alloys were induction melted and chill cast under a protective argon atmosphere in a high purity copper mold, to obtain cylindrical castings. Differential thermal analysis (DTA) of cast ingots was carried out to determine the transformation temperatures and select an optimum extrusion temperature. The castings were vacuum encapsulated in steel cans and extruded at $1400 \mathrm{~K}$, to an extrusion ratio of $32: 1$ for $\mathrm{NiAl}$ and $16: 1$ for $\mathrm{NiAl}(\mathrm{Cr})$. The chemical composition of the alloys was determined by an inductively coupled emission spectroscopy technique. The microstructures were examined by optical microscopy, following metallographic preparation and etching with saturated molybdic acid.

The as-extruded bars were centerless ground and machined for compressive (cylinders of length $1.25 \mathrm{~cm}$ and diameter $0.63 \mathrm{~cm}$ ), tensile (buttonhead specimens of gauge diameter $=0.3 \mathrm{~cm}$ and gauge length $3.0 \mathrm{~cm}$ ), and four-point bend notched fracture toughness (of length $2.54 \mathrm{~cm}$ and cross section $0.25 \mathrm{~cm} \times 0.25 \mathrm{~cm}$, with a notch $0.13 \mathrm{~cm}$ deep and $0.25 \mathrm{~cm}$ wide) tests. The compression tests were performed in air at a strain rate of $1.74 \times 10^{-4} \mathrm{~s}^{-1}$ in the temperature range 300-1000 K. The tensile specimens were electropolished prior to testing. The tensile tests were carried out in air at a strain rate of $1.3 \times 10^{-4} \mathrm{~s}^{-1}$ at 300 and $800 \mathrm{~K}$.

The fracture toughness was determined at room temperature by four-point bend testing of the notched bar specimens with the loading direction normal to the extrusion axis. For the compression specimens, the cracks originating at the specimen surface and propagating into the specimen interior were examined by scanning electron microscopy (SEM). These specimens were then cut normal to the compression axis and polished to examine the crack paths by optical metallography. The fracture surfaces after tensile and fourpoint bend tests were examined by SEM.

The microstructures of $\mathrm{NiAl}$ and $\mathrm{NiAl}(\mathrm{Cr})$ alloys were also examined using a Phillips $400 \mathrm{~T}$ transmission electron microscope operating at $120 \mathrm{kV}$. The compression test specimens, loaded till the yield point, were sectioned by electric discharge machining to obtain disks $3 \mathrm{~mm}$ in diameter. The transmission electron microscopy (TEM) specimens were obtained by electrochemical polishing these disks in a twin-jet Tenupol-3 polisher, using a solution of $70 \%$ ethanol, $14 \%$ distilled water, $10 \%$ butyl cellosolve and $6 \%$ perchloric acid, cooled to $263 \mathrm{~K}$. An applied potential of 20-50 V with a corresponding current of $10-15 \mathrm{~mA}$ produced the electron-transparent foils.

\section{Results}

The chemical compositions of the $\mathrm{NiAl}$ and $\mathrm{NiAl}(\mathrm{Cr})$ alloys were $\mathrm{Ni}-46 \mathrm{Al}$ and $\mathrm{Ni}-43 \mathrm{Al}-9.7 \mathrm{Cr}$ (atomic per cent) respectively. The carbon and oxygen contents of these alloys were lower than $0.012 \mathrm{wt} . \%$. The alloy densities were $5.45 \pm 0.01$ for $\mathrm{NiAl}$ and $5.57 \pm 0.05 \mathrm{~g} \mathrm{~cm}^{-3}$ for $\mathrm{Ni}-43 \mathrm{Al}-9.7 \mathrm{Cr}$.

\subsection{Microstructural characterization}

\subsection{1. $\mathrm{Ni}-43 \mathrm{Al}-9.7 \mathrm{Cr}$}

The solvus solidus and liquidus temperatures, marked V, T and D in the DTA plots (Fig. 1(a)), of $\mathrm{Ni}-43 \mathrm{Al}-09.7 \mathrm{Cr}$ alloy are 1478,1720 and $1818 \mathrm{~K}$. These are in reasonable agreement with the transformation temperatures of the $\mathrm{NiAl}-9.7 \mathrm{at} . \% \mathrm{Cr}$ alloy based on the phase diagram (Fig. 1(a)). The extrusion temperature of $1398 \mathrm{~K}$, (point E in Fig. 1(a)) lies in the $\beta+$ Cr two-phase field.

The microstructure of the as-cast Ni-43Al-9.7Cr alloy consisted of $\beta$-NiAl dendrites and the interdendritic NiAl-Cr eutectic (Fig. 2(a)). The extrusion microstructure consist of $\beta$-NiAl grains, aligned with the extrusion axis, and fine intergranular $\mathrm{NiAl}-\mathrm{Cr}$ eutectic (Figs. 2(b) and 2(c)). The $\beta$-NiAl grain size $(15 \mu \mathrm{m})$ of the extruded alloy (GFig. 2(c)) is much smaller than the grain size $(30 \mu \mathrm{m})$ of the as-cast alloy (Fig. 2(a)). Also, there is no evidence of recrystallization of the aligned primary $\mathrm{NiAl}$ grains.

\subsection{2. $\mathrm{Ni}-46 \mathrm{Al}$}

The extruded $\mathrm{Ni}-46 \mathrm{Al}$ showed an equiaxed grain morphology on both longitudinal and transverse (Fig. $2(d))$ sections, with relatively fine grain size (25-50 $\mu \mathrm{m})$, as a result of the recrystallization during and subsequent to the extrusion.

\subsubsection{TEM examination}

The TEM examination of specimens deformed just beyond the compressive yield stress (Figs. 3(a) and 3 (b)) shows that the $\mathrm{Ni}-43 \mathrm{Al}-9.7 \mathrm{Cr}$ matrix contains a bimodal distribution of $\alpha$-Cr precipitates about $15 \mathrm{~nm}$ in size, spaced at $50 \mathrm{~nm}$, and others about $45 \mathrm{~nm}$ in size, spaced at $150 \mathrm{~nm}$ (Fig. 3(a)). Extensive dislocation pinning associated with the chromium precipitates $45 \mathrm{~nm}$ in size is evident from Fig. 3(b). The chromium-alloyed NIAl specimens showed subgrain formation. This was not observed in Ni-46Al (Fig. $3(\mathrm{c}))$, which also showed the least amount of dislocations. 

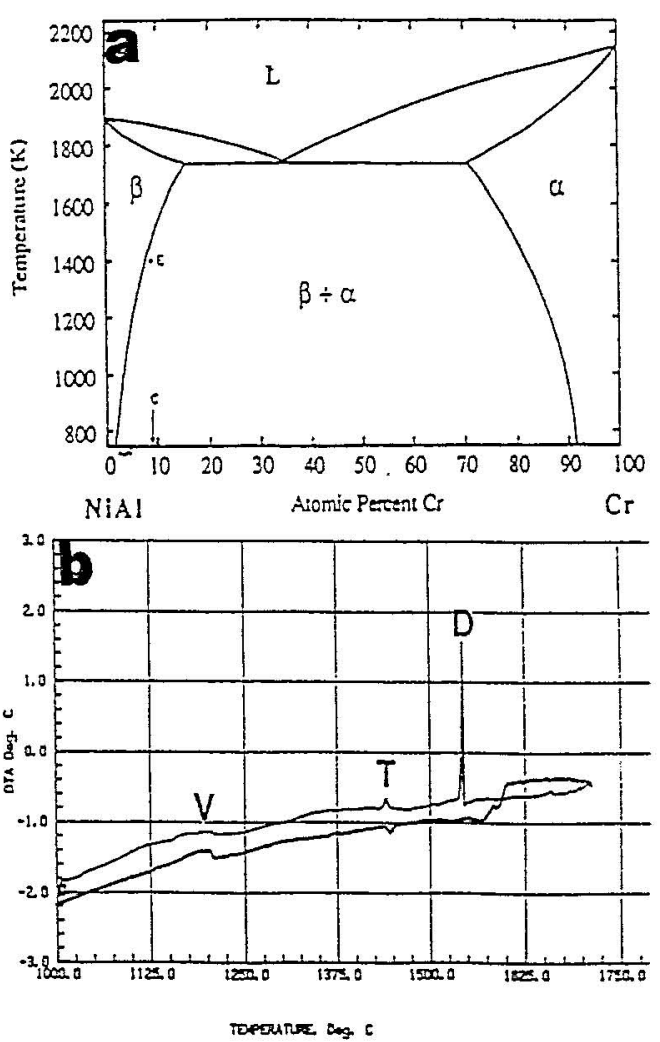

Fig. 1. (a) NiAl-rich portion of the pseudo-binary $\mathrm{NiAl}-\mathrm{Cr}$ eutectic phase diagram [10], with composition $\mathrm{C}$ of the $\mathrm{Ni}-43 \mathrm{Al}-9.7 \mathrm{Cr}$ alloy used in this study. Typical differential thermal analysis (DTA) plot obtained for the $\mathrm{Ni}-43 \mathrm{Al}-9.7 \mathrm{Cr}$ alloy.

\subsection{Compressive deformation and fracture}

The temperature dependence of the $0.2 \%$ offset compressive yield strength (CYS) of the extruded alloys (Fig. 4) shows that the room temperature CYS of the $\mathrm{Ni}-43 \mathrm{Al}-9.7 \mathrm{Cr}$ alloy $(895 \pm 90 \mathrm{MPa})$ is nearly twice that of the extruded $\mathrm{Ni}-46 \mathrm{Al}(451 \pm 6 \mathrm{MPa})$, and is also larger than the room temperature CYS of extruded $\mathrm{Ni}-45 \mathrm{Al}-5 \mathrm{Cr}$ alloy $(818 \pm 9 \mathrm{MPa})$ [3]. It is interesting to note that the room temperature CYS of extruded $\mathrm{Ni}-50 \mathrm{Al}(189 \pm 6 \mathrm{MPa}[3])$ is significantly lower than that of the alloys examined in this study.

The $\mathrm{Ni}-43 \mathrm{Al}-9.7 \mathrm{Cr}$ shows a higher CYS throughout the temperature range 300 to $1000 \mathrm{~K}$, compared with the Ni-46Al alloy. While the CYS of $\mathrm{Ni}-46 \mathrm{Al}$ decreases continuously with increasing temperature, the CYS of Ni-43Al-9.7Cr remains constant up to about $500 \mathrm{~K}$, after which it begins to decrease.

The fracture in Ni-46 Al is intergranular (Fig. 5), which is in agreement with the previous observations $[1,2]$. However, the $\mathrm{Ni}-43 \mathrm{Al}-9.7 \mathrm{Cr}$ alloy fractures in a mixed mode, with the crack propagation being both transgranular and intergranular. Its fracture surface gives a dimpled appearance (Fig. $6(\mathrm{~b})$ ) as opposed to the sharp faceted appearance in the extruded $\mathrm{Ni}-46 \mathrm{Al}$

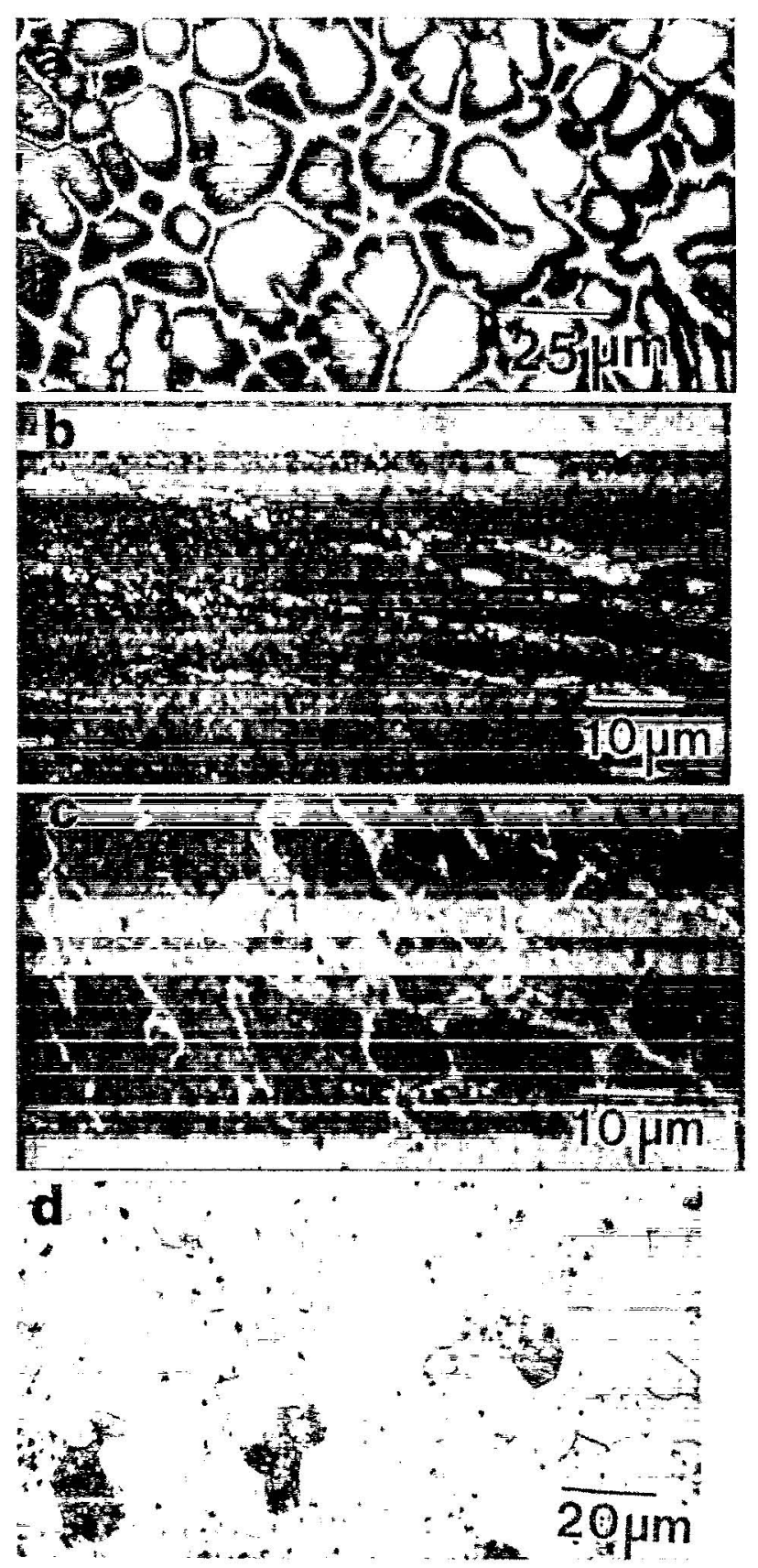

Fig. 2. Microstructures of (a) as-cast and (b), (c) extruded $\mathrm{Ni}-43 \mathrm{Al}-9.7 \mathrm{Cr}$; (b) transverse (normal to the extrusion direction) and (c) longitudinal views. (d) Transverse view of extruded NiAl.

(Fig. $5(b))$, as a result of the grain boundary decohesion. The dimpled appearance is caused by the pullout of the intergranular chromium phase. This indicates some toughening potential of the $\mathrm{Ni}-43 \mathrm{Al}-9.7 \mathrm{Cr}$ alloy.

At $800 \mathrm{~K}$, both the $\mathrm{Ni}-46 \mathrm{Al}$ (Fig. 7(a)) and $\mathrm{Ni}-43 \mathrm{Al}-9.7 \mathrm{Cr}$ (Fig. 7(b)) alloys showed transgranular fracture. While regions of inhomogeneous deformation (deformation bands) were observed in $\mathrm{Ni}-46 \mathrm{Al}$, these were not observed in $\mathrm{Ni}-43 \mathrm{Al}-9.7 \mathrm{Cr}$. For the extruded $\mathrm{Ni}-43 \mathrm{Al}-9.7 \mathrm{Cr}$ alloy, although the fracture at $800 \mathrm{~K}$ is 


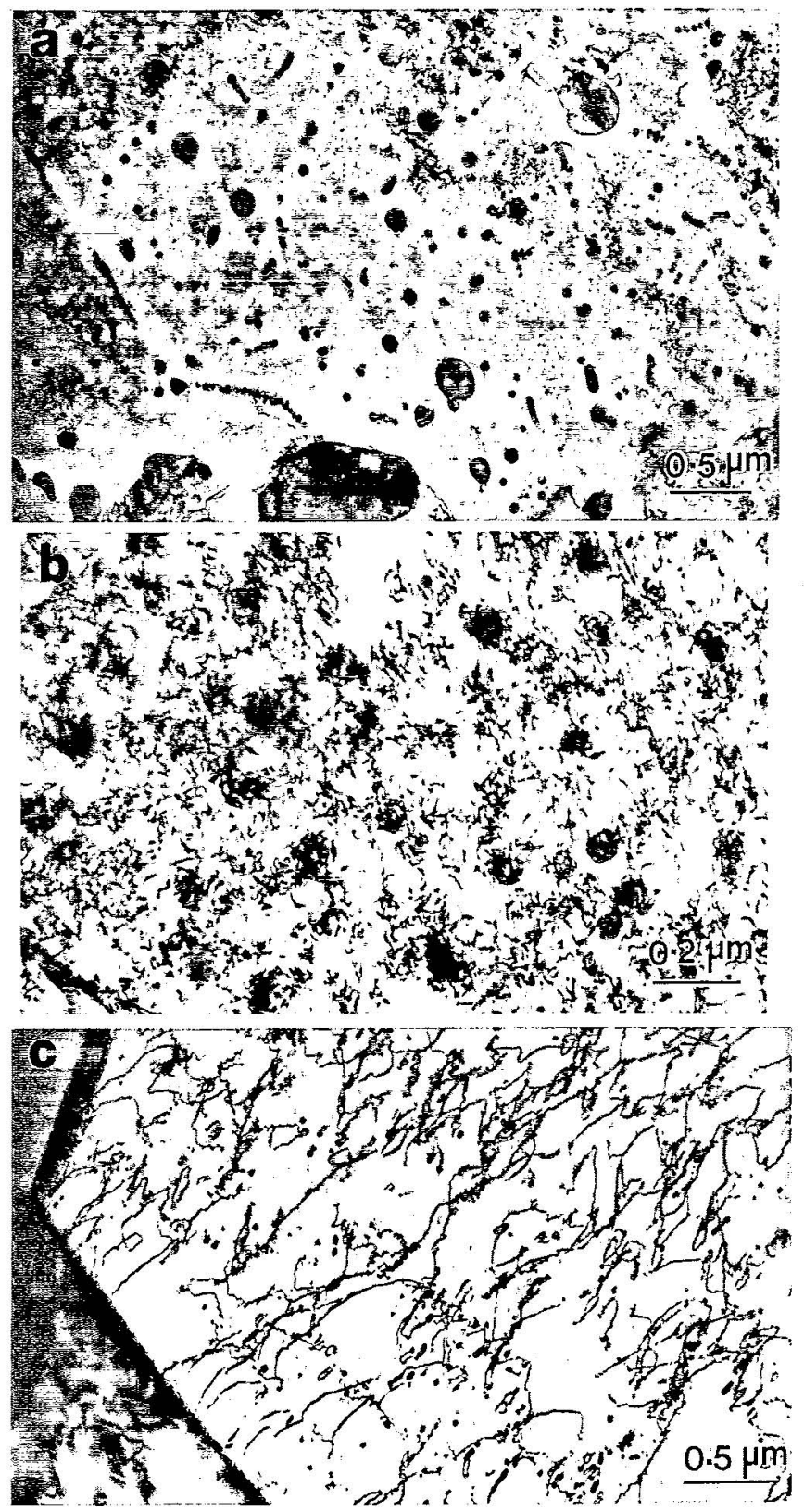

Fig. 3. TEM images of (a) Ni-43Al-9.7Cr, (b) Ni-43Al-9.7Cr alloy showing dislocation pinning by the $\alpha$-Cr precipitates, and (c) $\mathrm{Ni}-46 \mathrm{Al}$.

transgranular, the interdendritic $\mathrm{NiAl}-\mathrm{Cr}$ eutectic causes significant crack deflection (Fig. $7(\mathrm{~b})$ ).

\subsection{Tensile deformation and fracture}

The tensile properties of the extruded alloys have been summarized in Table 1 . The Ni-46 $\mathrm{Al}$ showed a brittle behavior (no yielding or plastic deformation), with a tendency for the specimens to fail in the grip, near the end of the gauge section. The yield strength value (indicated in Table 1 as a greater than the maximum observed stress) is greater than the value of 180 $\mathrm{MPa}$ for $\mathrm{NI}-50 \mathrm{Al}$ [3]. The plastic strain for the

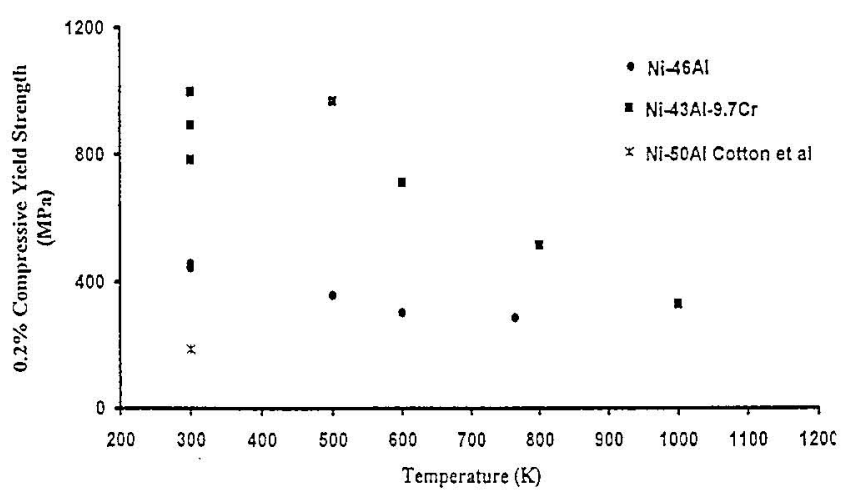

Fig. 4. Variation of $0.2 \%$ compressive yield strength (CYS) with temperature for the extruded $\mathrm{Ni}-46 \mathrm{Al}(\bullet)$ and $\mathrm{Ni}-43 \mathrm{Al}-9.7 \mathrm{Cr}$ (-) alloys, with results for $\mathrm{Ni}-50 \mathrm{Al}\left({ }^{*}\right)$ shown for comparison [3].

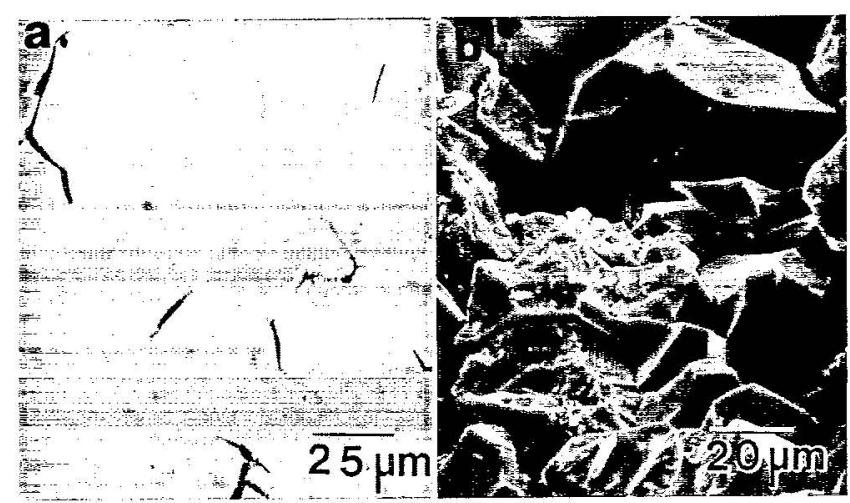

Fig. 5. (a) Optical micrograph showing crack path and (b) SEM view of fracture surface of extruded $\mathrm{Ni}-46 \mathrm{Al}$, compression tested at $300 \mathrm{~K}$, showing intergranular failure.

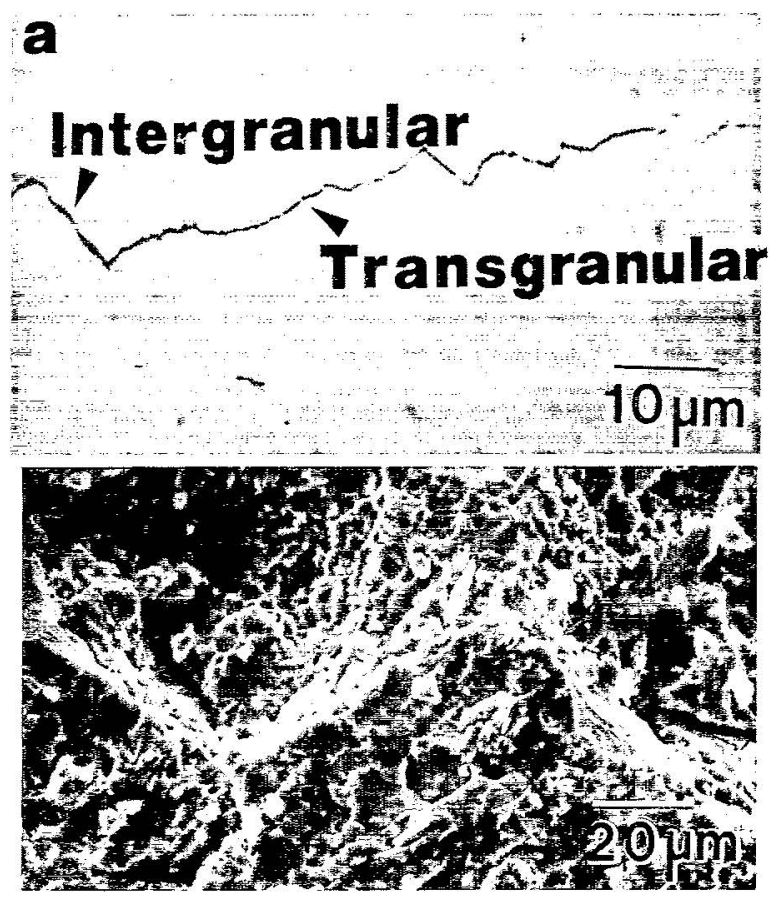

Fig. 6. (a) Optical micrograph showing crack path and (b) SEM view of fracture surface of extruded $\mathrm{Ni}-43 \mathrm{Al}-9.7 \mathrm{Cr}$ alloy, compression tested at $300 \mathrm{~K}$, showing mixed mode (transgranular and intergranular) fracture. 


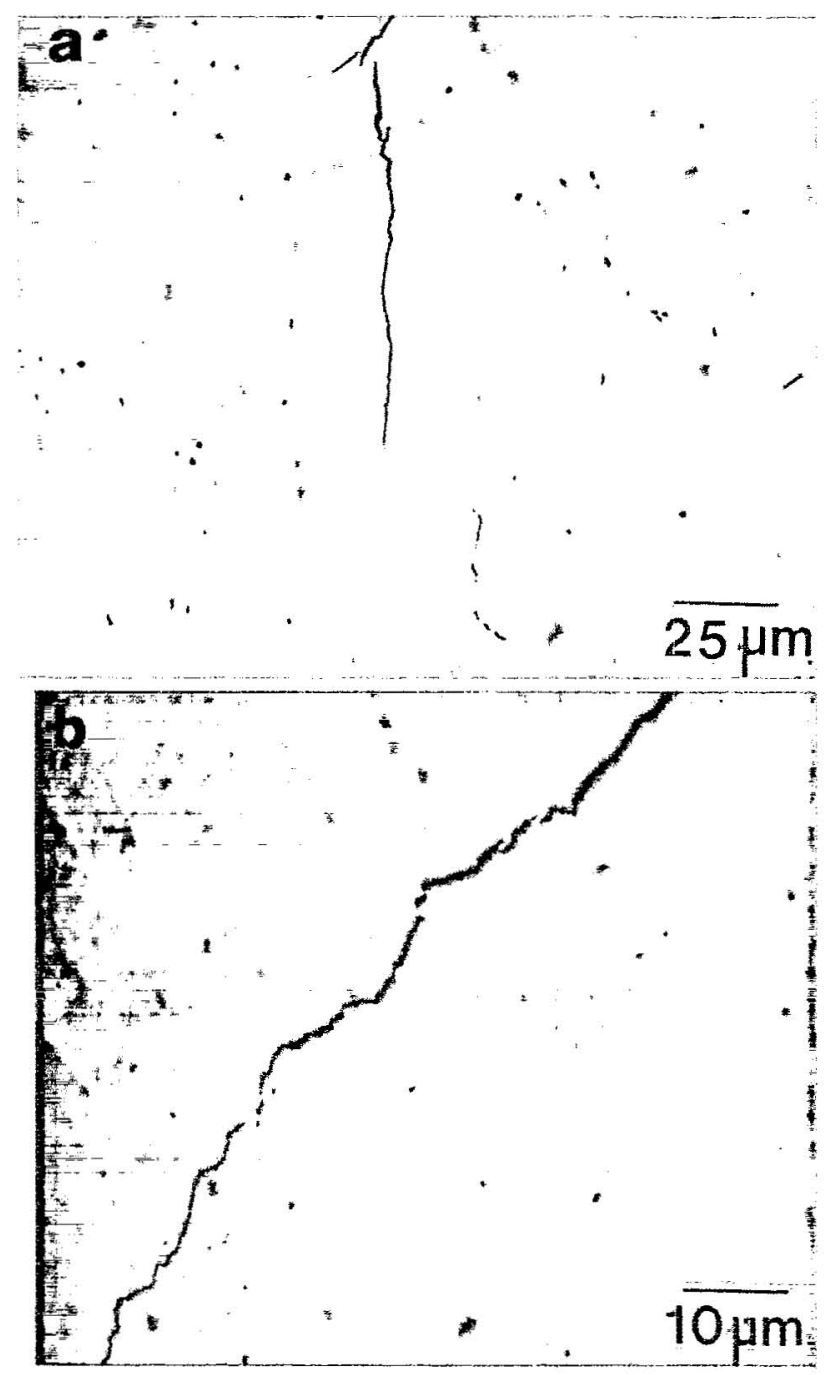

Fig. 7. Optical micrographs showing transgranular crack propagation in extruded (a) $\mathrm{Ni}-46 \mathrm{Al}$ and (b) Ni-43Al-9.7Cr, compression tested at $300 \mathrm{~K}$.
$\mathrm{Ni}-50 \mathrm{Al}$ is reported to be $1.5 \%[3]$ as compared with the zero ductility of the present $\mathrm{Ni}-46 \mathrm{Al}$ alloy. This is in agreement with the observation [13] that nickel-rich off-stoichiometry leads to an increased strength and decreased ductility for the $\mathrm{NiAl}$ alloys. This observation is also valid at higher temperatures. For example, the $\mathrm{Ni}-50 \mathrm{Al}$ alloy has a yield strength of $100 \mathrm{MPa}$ and ductility of $70 \%$ at $600 \mathrm{~K}$ [3], as compared with a yield strength of $253 \mathrm{MPa}$ and ductility of $6.3 \%$ for the $\mathrm{Ni}-46 \mathrm{Al}$ alloy at $800 \mathrm{~K}$.

The $\mathrm{Ni}-43 \mathrm{Al}-9.7 \mathrm{Cr}$ alloy showed a higher yield strength than the $\mathrm{Ni}-46 \mathrm{Al}$ alloy, both at the room temperature and at $800 \mathrm{~K}$. Its ductility was zero at room temperature and $3 \%$ at $800 \mathrm{~K}$. The ductility data at $800 \mathrm{~K}$ (Table 1) suggest that the brittle-ductile transition temperature (BDTT) of $\mathrm{Ni}-43 \mathrm{Al}-9.7 \mathrm{Cr}$ is greater than that of $\mathrm{Ni}-46 \mathrm{Al}$. The BDTT of NiAl alloys increases with increased deviation from stoichiometry $[14,15]$. The nickel-to-aluminum ratios for the $\mathrm{Ni}-43 \mathrm{Al}-9.7 \mathrm{Cr}$ and $\mathrm{Ni}-46 \mathrm{Al}$ alloys are 1.05 and 1.10 respectively. Therefore, one would expect $\mathrm{Ni}-46 \mathrm{Al}$ to have a higher BDTT than $\mathrm{Ni}-43 \mathrm{Al}-9.7 \mathrm{Cr}$. This is contrary to the observed behavior and may be attributed to the chromium alloying, which is known to increase the BDTT of NiAl alloys [3].

The fracture surface of the room temperature tensile-tested $\mathrm{NiAl}$ (Fig. 8(a)) is predominantly transgranular, with occasional intergranular failure. This is in agreement with earlier observations of transgranular failure in Ni-45Al by Nagpal and Baker [16]. The grain boundaries, however, appear to provide some resistance to the crack growth, as evidenced by the sharp facets observed along the grain boundaries on the fracture surface. For the $\mathrm{Ni}-43 \mathrm{Al}-9.7 \mathrm{Cr}$ alloy, the fracture is transgranular (Fig. $8(\mathrm{~b})$ ) and the chromium precipitates, located within the matrix and at the $\beta$ - $\mathrm{NiAl}$ grain boundaries, are pulled out during crack growth. This should result in improved fracture toughness.

Table 1

Tensile properties of $\mathrm{Ni}-46 \mathrm{Al}, \mathrm{Ni}-50 \mathrm{Al}{ }^{(3)}$ and $\mathrm{Ni}-43 \mathrm{Al}-9.7 \mathrm{Cr}$ alloys at 300 and $800 \mathrm{~K}$

\begin{tabular}{|c|c|c|c|c|c|}
\hline Alloy (Temperature) & $\begin{array}{l}0.2 \% \text { offset } \\
\text { compressive } \\
\text { yield strength } \\
(\mathrm{MPa})\end{array}$ & $\begin{array}{l}0.2 \% \text { offset } \\
\text { yield } \\
\text { strength } \\
(\mathrm{MPa})\end{array}$ & $\begin{array}{l}\text { Ultimate } \\
\text { tensile } \\
\text { strength } \\
\text { (MPa) }\end{array}$ & $\begin{array}{l}\text { Fracture } \\
\text { strain } \\
(\%)\end{array}$ & $\begin{array}{l}K_{\mathrm{c}} \\
\left(\mathrm{MPa} \mathrm{m}^{1 / 2}\right)\end{array}$ \\
\hline $\mathrm{NI}-46 \mathrm{Al}(300 \mathrm{~K})$ & 451 & $>279$ & - & 0 & 4.9 \\
\hline $\mathrm{Ni}-43 \mathrm{Al}-9.7 \mathrm{Cr}(300 \mathrm{~K})$ & 895 & $>496$ & - & 0 & 5.4 \\
\hline $\mathrm{Ni}-46 \mathrm{Al}(800 \mathrm{~K})$ & 288 & 253 & 352 & 6.3 & - \\
\hline $\mathrm{Ni}-50 \mathrm{Al}(300 \mathrm{~K})^{\mathrm{a}}$ & 189 & 180 & - & 1.5 & - \\
\hline $\mathrm{Ni}-50 \mathrm{Al}-0.28 \mathrm{Fe}(300 \mathrm{~K})^{\mathrm{b}}$ & 210 & 160 & 185 & - & - \\
\hline
\end{tabular}




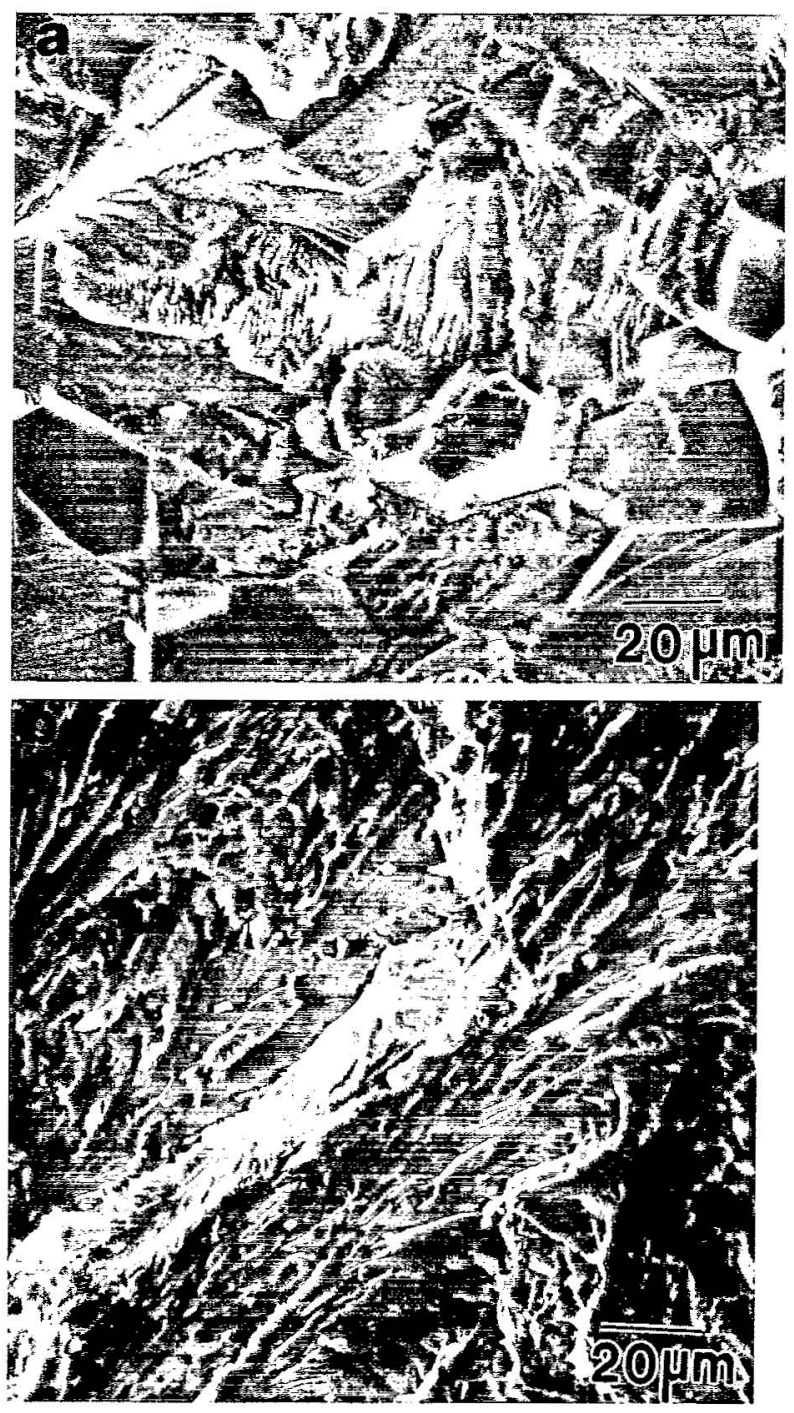

Fig. 8. Fracture surfaces of (a) Ni-46Al and (b) NMi-43Al-9.7Cr, tensile tested at room temperature.

\subsection{Fracture toughness}

The average values of the room temperature fracture toughness of $\mathrm{Ni}-46 \mathrm{Al}$ is $4.9 \mathrm{MPa} \mathrm{m}{ }^{1 / 2}$ (Table 1), which is in agreement with the values reported for polycrystalline $\mathrm{NiAl}$, i.e. $406 \mathrm{MPa} \mathrm{m}^{1 / 2}$ [4]. The $\mathrm{Ni}-43 \mathrm{Al}-9.7 \mathrm{Cr}$ alloy, with a $K_{\mathrm{c}}$ value of $5.4 \mathrm{MPa} \mathrm{m}^{1 / 2}$, showed a $10 \%$ increase in fracture toughness. The fracture for both these alloys was transgranular, and showed the characteristics described above for the room temperature tensile fracture, i.e. pulled out chromium particles for the $\mathrm{Ni}-43 \mathrm{Al}-9.7 \mathrm{Cr}$.

\section{Discussion}

\subsection{Microstructure}

Since the $\mathrm{NiAl}$ phase is considerably weaker than chromium at the extrusion temperatures (yield strength of $\mathrm{Ni}-50 \mathrm{Al}$ is less than $43 \mathrm{MPa}$ [3] at $800 \mathrm{~K}$, whereas it is $98 \mathrm{MPa}$ for chromium at $1073 \mathrm{~K}[17]$ ), the presence of the intergranular eutectic permits deformation only along the extrusion axis and yields the aligned microstructure (Fig. 2(c)). A microstructure (with small grain size) of the primary $\mathrm{NiAl}$ phase (which can be controlled by the rate of heat extraction during casting) is ideally suited for such extrusion processing in the two-phase regime.

\subsection{Mechanical properties}

The room temperature compressive yield strength of the Ni-46Al alloy $(451 \pm 6 \mathrm{MPa})$ is greater than that of the Ni-50Al (189 MPa) [3]. Assuming a linear dependence, this increase in strength corresponds to a strengthening rate of $66 \mathrm{MPa}$ per atomic per cent of nickel for the nickel-rich NiAl compositions, which is in agreement with the value deduced by Noebe et al. [2] (70 MPa per atomic per cent of nickel) from the tensile strength values of the nickel-rich cast and extruded $\mathrm{NiAl}$ alloys [13].

The microstructure, as observed in the extruded $\mathrm{Ni}-43 \mathrm{Al}-9.7 \mathrm{Cr}$ alloy, is expected to derive its strength from the following factors:

(1) Constitutional strengthening resulting from the variation in the nickel-to-aluminum ratio (66 $\mathrm{MPa}$ per atomic per cent of nickel, as determined in this study).

(2) Solid solution strengthening from the chromium dissolved in the NiAl phase. Cotton et al. [18] reported a solid solution hardening rate of $287 \mathrm{MPa}$ (per atomic per cent of chromium).

(3) Precipitation strengthening (chromium precipitates in the NiAl phase), i.e. the strength increment resulting from the obstruction of dislocation motion by non-shearing particles (dislocation pinning seen in Fig. $3(b)$ ) can be estimated, in a manner similar to Cotton et al. [3], by the expression

$$
\Delta \sigma_{\mathrm{p}}=\frac{G b}{2 \pi(\lambda-d)} \ln \left(\frac{d}{b}\right)
$$

where $G$ is the shear modulus ( $72 \mathrm{GPa}$ ), $b$ the Burgers vector $(0.2886 \mathrm{~nm}), d$ the chromium precipitate size $(45 \mathrm{~nm})$, and $\lambda$ the interparticle spacing $(150 \mathrm{~nm})$. The strengthening contribution from the finest chromium precipitates has been ignored, because dislocation pinning associated with these precipitates was not observed (Fig. 3(b)). These precipitates were apparently sheared because of the coherent interface between $\mathrm{NiAl}$ and $\mathrm{Cr}$.

(4) Grain size strengthening, where the yield strength of stoichiometric $\mathrm{Ni}-50 \mathrm{Al}$ is dependent on the grain size, and this dependence increases with the deviation from stoichiometry $[18,19]$. However, in 
$\mathrm{Ni}-43 \mathrm{Al}-9.7 \mathrm{Cr}$ alloy, the grain size of the primary $\beta$-NiAl phase $(15 \mu \mathrm{m})$ is considerably larger than the interparticle spacing between the chromium precipitates $(150 \mathrm{~nm})$. Therefore, the mean free path for the dislocations will be considerably less than the grain size; hence, grain size strengthening may be neglected.

Table 2 compares the estimated and measured CYS values of the $\mathrm{Ni}-43 \mathrm{Al}-9.7 \mathrm{Cr}$ and $\mathrm{Ni}-45 \mathrm{Al}-5 \mathrm{Cr}$ [3] alloys. The theoretical yield strength values have been computed by adding constitutional hardening $(66 \mathrm{MPa}$ per atomic per cent of nickel for nickel-rich $\mathrm{NiAl}$ ), solid solution hardening ( $287 \mathrm{MPa}$ per atomic per cent of chromium) [18], and precipitation hardening, to the yield strength of binary NI-50Al (189 MPa) [3]. Since the NI-45Al-5Cr alloy showed recrystallized $\beta$-NiAl grains having no interdendritic $\beta-\mathrm{NiAl}-\mathrm{Cr}$ eutectic [3], all the chromium in the alloy is assumed to be available for the solid solution and precipitation hardening of the matrix. As can be seen in Table 2, the difference between the experimental and estimated CYS values is less than $5 \%$ for both the $\mathrm{Ni}-45 \mathrm{Al}-5 \mathrm{Cr}$ and $\mathrm{Ni}-43 \mathrm{Al}-9.7 \mathrm{Cr}$ alloys.

An examination of Table 1 shows that the CYS values are greater than the tensile yield strengths. Similar behavior has been observed in the cast-plusextruded $\mathrm{Ni}-50 \mathrm{Al}[20]$ and $\mathrm{NiAl}-0.2$ at.\%Fe [21] alloys at room temperature. For the $\mathrm{Ni}-50 \mathrm{Al}$ alloy extruded from the vacuum-atomized powder, the compressive strengths were higher than the tensile strengths by 70 $\mathrm{MPa}$ and $20 \mathrm{MPa}$ at $500 \mathrm{~K}$ and $900 \mathrm{~K}$ respectively [20]. While this difference at $800 \mathrm{~K}$ for the $\mathrm{Ni}-46 \mathrm{Al}$ alloys is insignificant, it is considerably larger (72 MPa) for the NI-43Al-9.7 Cr alloy. This behavior can be likened to the Bauschinger effect, which is attributed to the interaction between the moving dislocations and the dislocation barriers. When the direction of loading is reversed, the pre-existing dislocations in the vicinity of the dislocation tangles (created by the previous deformation) move at a stress lower than that required for the previous loading. However, the exact mechan-

Table 2

Estimation of yield strengths of the $\mathrm{Ni}-45 \mathrm{Al}-5 \mathrm{Cr}$ and $\mathrm{Ni}-43 \mathrm{Al}-9.7 \mathrm{Cr}$ alloys

\begin{tabular}{lll}
\hline Strengthening mechanism & $\begin{array}{l}\mathrm{Ni}-45 \mathrm{Al}-5 \mathrm{Cr} \\
(\mathrm{MPa})\end{array}$ & $\begin{array}{l}\mathrm{Ni}-43 \mathrm{Al}-9.7 \mathrm{Cr} \\
(\mathrm{MPa})\end{array}$ \\
\hline Binary Ni-50Al $^{\mathrm{a}}$ & 189 & 189 \\
Solid solution strengthening $^{\mathrm{b}}$ & 431 & 431 \\
Constitutional strengthening $^{\mathrm{N}}$ & 174 & 157 \\
Precipitation strengthening & 53 & 159 \\
Estimated yield strength & 847 & 937 \\
Experimental yield strength & $818^{\mathrm{a}}$ & 895 \\
\hline
\end{tabular}

aAfter ref.[3].

bAfter ref. [19]. ism of this behavior in our alloys is presently not understood.

\section{Conclusions}

(1) Extrusion of dual-phase microstructures prevents the dynamic recrystallization that is commonly observed in single-phase NiAl.

(2) The compressive yield strengths for the extruded alloys are larger than the tensile yield strengths, presumably because of a Bauschinger-like effect. Their difference decreases with increasing temperature.

(3) Chromium alloying leads to a two fold increase in the yield strength of NiAl, primarily because of solid solution strengthening, and precipitation strengthening.

(4) The deviation from stoichiometry in $\mathrm{NiAl}$ alloys affects their mechanical behavior by increasing the BDTT, lowering the room temperature tensile ductility, and increasing the $0.2 \%$ offset yield strength.

(5) The constitutional hardening for nickel-rich $\mathrm{NiAl}$ alloys, attributed to the deviation from stoichiometry, is about $66 \mathrm{MPa}$ per atomic per cent of nickel.

\section{Acknowledgments}

This research was partially supported by a grant from the NASA Lewis Research Center (Grant NCC3-287). Appreciation is expressed to Dr. J.D. Whittenberger for providing extruded material, and to R.R. Toothman, R.E. Phillips, and W. Karpinski for assistance with the mechanical testing of the specimens. Continuous encouragement by T.K. Glasgow is gratefully acknowledged.

\section{References}

[1] D.B. Miracle, Acta Metall. Mater., 41 (3) (1993) 649-684.

[2] R.D. Noebe, R.R. Bowman and M.V. Nathal, Int. Met. Rev, $38(4)(1993) 193-232$.

[3] J.D. Cotton, R.D. Nocbe and M.J. Kaufman, Intermetallics, 1(1993) 3-29.

[4] K.S. Kumar, S.K. Mannan and R.K. Viswanadham, Acta Metall. Mater., 40(6) (1992) 1021-1222.

[5] R. Darolia, D. Lahrman and R. Field, Scr. Metall. Mater, 126(1992) 1172-1012.

[6] R.D. Noebe, A. Misra and R. Gibala, ISIJ., 31 (10) (1991) 1172-1185.

[7] S.N. Tewari, NASA TN D-8355, 1977.

[8] D.R. Pank, M.V. Nathal and D.A. Koss, J. Mater. Res., 5 (1990) 942-949.

[9] K. Ishida, R. Kainuma, N. Ueno and T. Nishizawa, Metall. Trans. A, 22A (1991) 441-446.

[10] S. Guha, P.R. Munroe and I. Baker, Mater. Res. Soc. Symp. Proc., 133 (1989)633-638. 
[11] R. Gibala, H. Chang, C.M. Czarnik, K.M. Edwsards and A. Misra, in R. Darolia, J.J. Lewandowski, C.T. Liu, P.L. Martin, D.B. Miracle and M.V. Nathal (eds.), Structural Intermetallics, The Minerals and Metals Society, 1993, pp. 561-567.

[12] J.D. Cotton, R.D. Noebe and M.J. Kaufman, NiAl-rich portion of the NiAl-Cr pseudobinary eutectic system, submitted to Phase Equilibria.

[13] K.H. Hahn and K. Vedula, Scr. Metall. Mater, 23 (1989) $7-12$.

[14] J.H. Westbrook, H.E. Grnoble and D.L. Wood, WADD-TR60-184, Pt V, 1964, p. 22.

[15] C.C. Law and M.J. Blackburn, Rapidly solidified lightweight durable disk material, Final Tech. Rep. AFWAL-TR87-4102, 1987.
[16] P. Nagpal and I. Baker, Mater. Character., 27 (1991) 167-173.

[17] Metals Handbook, American Society for Metals, Metals Park, OH, 1985.

[18] J.D. Cotton, R.D. Noebe and M.J. Kaufman, in R. Darolia, J.J. Lewandowski, C.T. Liu, P.L. Martin, D.B. Miracle and M.V. Nathal (eds.), Structural Intermetallics, The Minerals and Metals Society, 1993, pp. 513-522.

[19] I. Baker, P. Nagpal, F. Liu and P.R. Munroe, Acta Metall. Mater., 39 (1991) 1637.

[20] R.R. Bowman, R.D. Noebe, S.V. Raj and I.E. Locci, Metall. Trans. A, 23 (1992) 1493-1508.

[21] K. Matsugi, D.W. Wenman and N.S. Stoloff, Scr. Metall., 27 (1992) 1633-1638. 